\title{
Corneal ulceration at an urban African hospital
}

\author{
T R CARMICHAEL, M WOLPERT, AND H J KOORNHOF
}

From the Department of Ophthalmology, University of the Witwatersrand, Johainnesburg, South Africa

\begin{abstract}
SUMmARY During a one-year survey 283 corneal ulcers from 274 patients were seen at St John's Eye Unit of Baragwanath Hospital. Central bacterial ulcers constituted the largest problem, and the commonest isolate in this group was Streptococcus pneumoniae. Mycotic and dendritic keratitis were relatively uncommon, while marginal catarrhal ulceration secondary to chronic staphylococcal lid disease was frequently seen. The microbiology of the various ulcers is described, and the placing of organisms into classes is stressed in determining significance of isolates. Many of the patients were male Africans who were either manual labourers or unemployed. Half the patients had used topical antibiotics before presentation.
\end{abstract}

The spectrum of micro-organisms responsible for corneal ulceration varies according to geographical location. Reports from the northern parts of the United States of America show predominantly Gram-positive organisms ${ }^{\prime 2}$ while the southern parts show a striking number of fungal and Gram-negative isolates. ${ }^{3} \mathrm{~A}$ recent study from Britain ${ }^{4}$ also showed predominantly Gram-positive isolates. Variations such as these are probably worldwide, but studies of them have not been forthcoming from many areas. Relatively little is known about the situation in Africa. A report from Nigeria in $1976^{5}$ concentrated on cases of mycotic keratitis selected from the 'large number of patients with corneal ulcers' treated at that hospital.

Baragwanath Hospital serves the population of Soweto, a sprawling city near Johannesburg, South Africa, whose inhabitants number about one million. In addition Baragwanath Hospital is a referral centre for medical problems from many parts of the country and occasionally further afield. The St John's Eye Unit is an integral part of the hospital and is adjacent to it. Cases of corneal ulceration constitute about $5 \%$ of admissions to St John's Eye Unit. The present survey was intended to establish the numbers of the various types of corneal ulcers seen at the hospital, the spectrum of micro-organisms isolated, and to collect data relating to local and general predisposing factors with a view to prophylactic intervention should this be possible.

Correspondence to $\operatorname{Dr} T \mathbf{R}$ Carmichael, Department of Ophthalmology, Medical School, York Road, Parktown, Johannesburg, 2193 South Africa.

\section{Material and methods}

PATIENTS

Patients with corneal ulcers were divided into mild, moderate, and severe groups. The mild group contained patients with corneal ulcers considered suitable for outpatient treatment. Patients with moderate and severe corneal ulcers were admitted for intensive investigation and treatment. The severe cases had features of severity as defined by Jones. ${ }^{6}$ Ulceration due to chemical burns and simple traumatic ulcers without secondary infection were excluded from the study group.

From the beginning of July 1982 to the end of June 1983113 cases of mild corneal ulceration (116 eyes) and 161 moderate and severe cases (167 eyes) were treated. The mild group was treated in the outpatient department by a number of different doctors, and treatment methods varied.

Recording sheets were used to detail relevant history and examination, and a drawing of the cornéa was made along the lines suggested by Bron' and Harrison. ${ }^{8}$ Anterior segment photography recorded the appearance of the ulcer on admission, discharge, and when otherwise indicated.

\section{CULTURE TECHNIQUES}

All cultures except two were taken prior to admission by the doctor supervising the cases, and the other two were cultured under direct supervision by the same technique.

The culture technique was as advocated by Jones. ${ }^{9}$ Conjunctival specimens were taken with calcium alginate swabs (Calgiswab, Inolex) moistened in 
serum broth. One was swabbed over the lower fornix, avoiding the lid margins, plated on to blood agar, and inoculated into serum broth. A second swab was moistened in chopped meat broth and a conjunctival swab taken in the same way and placed in the chopped meat broth. The cornea was then anaesthetised with oxybuprocaine or proparacaine hydrochloride. Multiple corneal scrapings were then taken with platinum spatulae and inoculated on to blood agar in several rows, and serum broth and brain-heart infusion broth were also inoculated. From corneal scrapings two smears were made, one of which was stained the same day with Gram's staining technique, while the other was examined microscopically the following day by the Mycology Department. A swab moistened in chopped meat broth was rubbed over the base and edges of the ulcer and inserted into the chopped meat broth. The chopped meat broth replaced a brain-heart infusion broth under oil which was used for the first four months of the study ( 80 cases) and during which time no anaerobic bacteria were grown. In 54 cases a dry cotton swab was used to take a specimen for viral culture, and this was placed in bovine plasma albumin for transport to the laboratory. In 30 cases corneal scrapings were plated on to Lowenstein and Jensen media to check specifically for mycobacteria, as tuberculosis is not uncommonly treated at Baragwanath Hospital. The viral cultures were kept at $4^{\circ} \mathrm{C}$ and the rest of the specimens were incubated overnight. The serum broths were incubated in $10 \%$ $\mathrm{CO}_{2}$ to enhance the growth of more fastidious organisms. Swabs moistened in serum broth were used to take lid margin cultures from the same eye in cases of marginal corneal ulcer, and these were plated on to blood agar.

Bacteria were classified according to Bergey's Manual. ${ }^{10}$ Conventional microbiological techniques were used for the isolation and identification of bacteria, fungi, and viruses isolated. All specimens were processed by the Central SAIMR (South African Institute for Medical Research), Johannesburg, except for virology specimens, which were forwarded to the National Institute for Virology.

\section{CLASSIFICATION OF ISOLATES}

The following classification to determine the significance of bacterial isolates, suggested by Jones, ${ }^{6}$ was used:

Class 1. Growth of any organism(s) in two or more corneal media.

Class 2. Growth (more than one colony) in one solid medium of Staphylococcus aureus, Streptococcus pneumoniae, or Pseudomonas aeruginosa.

Class 3. Growth in one medium of an organism identified in the direct smear.
In addition to these three classes it was found useful to consider two other situations for clinical purposes, though these may not be acceptable in terms of a case definition:

Class 4. Growth of any organism(s) in a corneal medium plus conjunctival media.

Class 5. Growth of a pathogen on conjunctival media only.

As anaerobic bacteria were cultured from a single corneal and conjunctival medium these were not placed in the above mentioned classes.

A simple classification of the ulcers was used according to a method similar to that described by Kumura. ${ }^{11}$

\section{Results}

The number of ulcers in each category is shown in Table 1 . There was a slight seasonal variance in the presentation of the ulcers to the hospital with a peak late in winter and into spring. There were 79 right and 76 left eyes with unilateral ulcers, and these together with the six bilateral cases gave 161 patients with 167 ulcers. Three of the bilateral cases were marginal catarrhal. There was no significant difference in mean age between the two largest groups. The central bacterial group had a mean age of 42.5 years and the marginal catarrhal group a mean age of 44.9 years. Within the group of admitted patients 30

Table 1 Types of corneal ulcers

\begin{tabular}{lll}
\hline Type of ulcer & \multicolumn{2}{l}{ Number of eyes } \\
\cline { 2 - 3 } & $\begin{array}{l}\text { Mild } \\
\text { (outpatients) }\end{array}$ & $\begin{array}{l}\text { Moderate and severe } \\
\text { (admitted cases) }\end{array}$ \\
\hline Central: & & \\
Bacterial & 30 & 91 \\
Fungal & 0 & 6 \\
Viral & 24 & 13 \\
Other & 0 & 0 \\
Marginal: & 30 & 30 \\
Catarrhal & 4 & 12 \\
Ring/melting & 0 & 4 \\
Mooren's & 0 & 6 \\
Primary infection & 28 & 5 \\
Other & 116 & 167 \\
Total & & \\
\hline
\end{tabular}

Table 2 Occupation of adult corneal ulcer patients

\begin{tabular}{lcc}
\hline Type of work & Number & Percentage \\
\hline Manual labourer (non-farm) & 61 & 47 \\
Manual labourer (farm) & 8 & 6 \\
Unemployed & 33 & 25 \\
Domestic worker & 16 & 12 \\
Pensioner & 11 & 8 \\
Clerical & 2 & 2 \\
Total & 131 & 100 \\
\hline
\end{tabular}


Table 3 Comparison of numbers of central bacterial and marginal catarrhal corneal ulcers in the various ethnic groups

\begin{tabular}{lcc}
\hline Ethnic group & Central bacterial & Marginal catarrhal \\
\hline Zulu & 26 & 11 \\
Sotho & 22 & 9 \\
Xhosa & 8 & 4 \\
Tswana & 7 & 2 \\
Ndebele & 6 & 1 \\
Swazi & 6 & 1 \\
Shangaan & 5 & 0 \\
Coloured & 3 & 0 \\
Venda & 1 & 0 \\
Indian & 1 & 0 \\
Not known/other & 6 & 2 \\
Total & 91 & 30 \\
\hline
\end{tabular}

Table 5 Delay before presentation for treatment

\begin{tabular}{llc}
\hline Type of ulcer & Mean (days) & Number in group \\
\hline Central: & & \\
$\quad$ Bacterial & 11 & 82 \\
$\quad$ Fungal & 26 & 6 \\
$\quad$ Viral & 10 & 13 \\
Marginal: & & 29 \\
$\quad$ Catarrhal & 19 & 12 \\
Ring & 34 & 3 \\
Mooren's & 43 & 5 \\
Primary infection & 27 & 4 \\
$\quad$ Other & 9 & 154 \\
Total & & \\
\hline
\end{tabular}

Table 6 Local treatment of corneal ulcers before admission Central group (110 ulcers)

\begin{tabular}{lrlll}
\hline & Bacterial & Fungal & Viral & Total \\
\hline Antibiotic: & & & & \\
$\quad$ Definite & 16 & 3 & 2 & $21)$ \\
$\quad$ Probable & 22 & 0 & 5 & 27 \\
$\quad$ plus Steroid & 2 & 0 & 1 & 3 \\
$(46 \%$ of \\
central ulcers $)$ \\
Steroid only & 3 & 0 & 1 & 4 \\
Antiviral & 0 & 1 & 0 & 1 \\
Other & 19 & 0 & 2 & 21 \\
Total & 62 & 4 & 11 & $77(70 \%$ of \\
& & & & central ulcers $)$ \\
\hline
\end{tabular}

Table 4 Comparison of numbers of central bacterial and marginal catarrhal corneal ulcers for males and females

\begin{tabular}{llc}
\hline Sex & Central bacterial & Marginal catarrhal \\
\hline Male & 79 & 21 \\
Female & 12 & 9 \\
Total & 91 & 30 \\
\hline
\end{tabular}

ulcers occurred in children (16 years of age and younger). Of the adults half were manual labourers and a quarter were unemployed (Table 2).

Of the cases which were admitted to hospital, $39 \%$ originated from Soweto, $48 \%$ from other urban areas within the Transvaal province, and $13 \%$ from rural areas within the Transvaal Province. Tables 3 and 4 show the ethnic and sex distribution of patients with corneal ulcers in the two largest ulcer groups.

In 154 cases the mean delay between the onset of symptoms and presentation to St John's for treatment was 16 days, but there was marked variation depending on the type of ulcer (Table 5). There was a significantly longer $(p<0.05$, Student's $t$ test) delay before referral for the marginal catarrhal group than with the central bacterial group. About half the patients had been previously treated with topical antibiotics, and the antibiotic varied according to the type of ulcer being treated (Table 6). In 11 cases oral antibiotics had certainly been given in addition to local treatment. In a further five cases the description of the tablets suggested that they were antibiotics. Only one patient was on systemic steroid therapy, and this was a case of systemic lupus erythematosus with keratitis sicca which developed a pseudomonas corneal ulcer.

\section{MICROBIOLOGY OF CENTRAL CORNEAL ULCERS} Corneal isolates were obtained in 62 of the 91 eyes in the central bacterial group (Table 7). By far the commonest isolate was Str. pneumoniae, which was cultured from 26 eyes. Other streptococcus species were isolated from a further four eyes. Of the pneumococci which were isolated from the central

Marginal Group (57 ulcers)

\begin{tabular}{|c|c|c|c|c|c|c|}
\hline & Catarrhal & Ring & Mooren's & $\begin{array}{l}\text { Primary } \\
\text { infect. }\end{array}$ & Other & Total \\
\hline \multicolumn{7}{|l|}{ Antibiotic: } \\
\hline Definite & 7 & 4 & 1 & 3 & 1 & 16) 31 \\
\hline Probable & 8 & 2 & 1 & 0 & 1 & $12\}(54 \%$ of \\
\hline plus Steroid & 1 & 1 & 0 & 0 & 1 & 3 marginal ulcers) \\
\hline Other & 4 & 2 & 0 & 0 & 1 & 7 \\
\hline Total & 20 & 9 & 2 & 3 & 4 & $\begin{array}{l}38(67 \% \text { of } \\
\text { marginal ulcers })\end{array}$ \\
\hline
\end{tabular}

Antibiotic: 'Definite'- the patient could produce the antibiotic or knew the name; 'probable'- the patient was using ointment, or drops and ointment, which had been obtained from a medical source such as a doctor, clinic or chemist; 'other'-the patient was using drops only, which may or may not have contained antibiotic. 
bacterial ulcers four were isolated from children, three of whom were under 5 years old. From all types of ulcers there were 29 pneumococcal isolates, of which 24 were typed. Type 6 was the commonest (six isolates), followed by type 10 (four isolates). These and the eight other types reflected the usual upper respiratory tract pneumococci in the area. Minimal inhibitory concentrations (MICs) of drugs against 12 pneumococcal isolates were determined and they were all susceptible to penicillin-G MIC levels at $<0.01 \mu \mathrm{g} / \mathrm{ml}$ except one which had an MIC of $0.25 \mu \mathrm{g} / \mathrm{ml}$.

Staph. aureus was not found to be a common cause of central corneal ulceration in this survey. Isolates of Gram-negative bacteria were obtained from 18 eyes, with Pseudomonas aeruginosa (nine isolates) being the most common, followed by Moraxella species (four significant isolates).

In class 5 (conjunctival pathogens) there were three isolates of Staph. aureus, two of Proteus mirabilis, and one each of Ps. aeruginosa and Str. pneumoniae.

The anaerobes cultured were all obtained from chopped meat broth and consisted of nine isolates from eight cases. Four were conjunctival isolates only, and, of the remaining five, two were isolated in conjunction with class 1 pneumococci and were not considered significant in their own right. The remaining three were possibly significant. The case shown in Table 7 suffered from severe bullous keratopathy, and there were no aerobic bacteria cultured from the ulcer. The Peptococcus prevotii was cultured from the cornea and a Peptococcus asaccharolyticus was isolated from the conjunctiva. Scanty Gram-positive cocci were seen on the direct smear from the cornea. The other two isolates, a Peptococcus micros and a Propionibacterium acnes were not confirmed on direct smear and are thus probably not significant.

The Lowenstein-Jensen media were all negative for mycobacteria. The isolates from the cases of fungal keratitis are listed in Table 8 together with some of their relevant clinical details. None of the cases gave a history of trauma and none was wearing a contact lens. The nodular form of climatic droplet keratopathy which flakes off, leaving an area denuded of epithelium, was seen in two of these cases (it was also a local predisposing factor in eight of the central bacterial ulcers). As might be expected, half the group came from rural areas. There was only one significant bacterial isolate in this group and that was a class 1 Staph. epidermidis from case 5.

The group of central viral ulcers consisted largely of cases of indolent corneal ulceration with loss of corneal sensation. In some cases a clinical diagnosis could be made of stromal herpes keratitis with ulceration, and in one of these cases Herpes simplex
Table 7 Corneal isolates from central bacterial ulcers

\begin{tabular}{|c|c|c|}
\hline & Organism & Number of isolates \\
\hline \multicolumn{3}{|l|}{ Single isolates } \\
\hline \multirow[t]{9}{*}{ Class 1: } & Streptococcus pneumoniae & 20 \\
\hline & Pseudomonas aeruginosa & 9 \\
\hline & Staphylococcus aureus & 3 \\
\hline & Corynebacterium species & 2 \\
\hline & Staph. epidermidis & 2 \\
\hline & Str. sanguis & 2 \\
\hline & Proteus mirabilis & 2 \\
\hline & Moraxella lacunata & 1 \\
\hline & Klebsiella pneumoniae & 1 \\
\hline Class 2: & Str.pneumoniae & 1 \\
\hline \multirow[t]{3}{*}{ Class 3: } & Moraxella lacunata & 3 \\
\hline & Str. pneumoniae & 1 \\
\hline & Corynebacterium species & 1 \\
\hline \multirow[t]{3}{*}{ Class 4: } & Staph. epidermidis & 2 \\
\hline & Corynebacterium species & 1 \\
\hline & Moraxella species & 1 \\
\hline \multirow{2}{*}{$\begin{array}{l}\text { Anaerobe: } \\
\text { Total }\end{array}$} & Peptococcus prevotii & 1 \\
\hline & & $\begin{array}{l}53 \text { isolates } \\
\text { from } 53 \text { cyes }\end{array}$ \\
\hline \multicolumn{3}{|c|}{ Mixed isolates (class of isolates ${ }^{*}$ in brackets) } \\
\hline \\
\hline \multicolumn{3}{|c|}{ Str. pneumoniae (2) + Staph. epidermidis (4) } \\
\hline \multirow{2}{*}{\multicolumn{3}{|c|}{ Str. pneumoniae (1) + Propionibacterium acnes }} \\
\hline & & \\
\hline \multicolumn{3}{|c|}{$\begin{array}{l}\text { Str. pneumoniae (1) + Pasterurella species (4) } \\
\text { M. lacunata }(3)+\text { Corynebacterium species (1) }\end{array}$} \\
\hline \multicolumn{3}{|c|}{ M. lacunata (1) + Staph. epidermidis (1) } \\
\hline \multirow{2}{*}{\multicolumn{3}{|c|}{$\begin{array}{l}\text { Staph. epidermidis }(4)+\text { Corynebacterium species }(4) \\
\text { Str. pyogenes }(1)+\text { Staph. epidermidis }(1) \text { : this combination was } \\
\text { isolated from both eyes of a case of bilateral corneal ulceratior }\end{array}$}} \\
\hline & & \\
\hline \multirow{2}{*}{\multicolumn{2}{|c|}{ Total }} & 18 isolates \\
\hline & & from 9 eyes \\
\hline
\end{tabular}

*For description of classes of isolates see 'Materials and methods'.

Table 8 Corneal isolates from central fungal ulcers

\begin{tabular}{llll}
\hline Isolate & $\begin{array}{l}\text { Class of } \\
\text { isolate }\end{array}$ & Rural & $\begin{array}{l}\text { Predisposing } \\
\text { factor }\end{array}$ \\
\hline Aspergillusflavus & 1 & Yes & Diabetic \\
Phoma eupyrena* $_{\text {Candida guilliermondii }}$ & $1 \dagger$ & No & Climatic droplet \\
Fusarium moniliforme* $^{*}$ & $1 \dagger$ & No & Diabetic \\
Curvularia lunata* $^{*}$ & BHI & No & Nil \\
Curvularia lunata* $_{1}$ & $1 \dagger$ & Yes & Cliabetic, renal \\
& & &
\end{tabular}

*Identification confirmed at the Identification Services,

Commonwealth Mycological Institute, Surrey, England.

†Confirmation of fungus on direct smear.

BHI=Fungus cultured from brain heart infusion broth only after repeated corneal scraping in clinically suggestive cases.

Climatic droplet means climatic droplet keratopathy.

was isolated. There was only one dendritic ulcer in this group.

MICROBIOLOGY OF MARGINAL CORNEAL ULCERS The organisms isolated from the marginal catarrhal group are shown in Table 9.

Direct smears were helpful in 85 of the 128 instances $(66 \%)$, in which one was done (see Table 10). 
Table 9 Corneal isolates from marginal catarrhal ulcers

\begin{tabular}{|c|c|c|}
\hline Organism & $\begin{array}{l}\text { Number of } \\
\text { isolates }\end{array}$ & Class of isolate ${ }^{*}$ \\
\hline \multicolumn{3}{|l|}{ Single isolates } \\
\hline Staphylococcus aureus & 6 & $1,1,1,3,4,4$ \\
\hline Corynebacterium species & 3 & $1,4,4$ \\
\hline Staph. epidermidis & 2 & 1,4 \\
\hline Corynebacterium hofmanii & & 4 \\
\hline Streptococcus pneumoniae & 1 & 1 \\
\hline Propionibacterium acnes & & \\
\hline Total & $\begin{array}{l}14 \text { isolates from } \\
14 \text { eyes }\end{array}$ & \\
\hline \multicolumn{3}{|c|}{$\begin{array}{l}\text { Mixed isolates (classes in brackets) } \\
\text { Proteus mirabilis (4), Str. pneumoniae (4) } \\
\text { Staph. aureus (1), Str. pyogenes (1) } \\
\text { Staph. aureus (1), Str. pyogenes }(1) \\
\text { Str. anginosus (1), Neisseria flava }(4) \\
\text { Str. anginosus (1), N. flava }(1), \text { Proteus vulgaris }(1)\end{array}$} \\
\hline Total & & $\begin{array}{l}11 \text { isolates from } 5 \text { eyes } \\
\text { (the last } 2 \text { eyes were } \\
\text { from a bilateral case) }\end{array}$ \\
\hline
\end{tabular}

*For description of classes of isolates see 'Material and methods'.

Table 10 Results of microscopy of smears

\begin{tabular}{|c|c|c|c|c|}
\hline \multirow[t]{2}{*}{ Result } & \multicolumn{2}{|c|}{ Ulcergroup (numbers) } & \multicolumn{2}{|l|}{ Total } \\
\hline & Central & Marginal & Number & Percentage \\
\hline Organism identified & 40 & 7 & 47) & $37)$ \\
\hline $\begin{array}{l}\text { Slide negative, } \\
\text { Culture negative }\end{array}$ & 23 & 15 & $38\}^{85}$ & $29\}^{66}$ \\
\hline $\begin{array}{l}\text { Slide negative, } \\
\text { Culture positive }\end{array}$ & 21 & 20 & 41 & 32 \\
\hline $\begin{array}{l}\text { Slide positive, } \\
\text { Culture negative }\end{array}$ & 2 & 0 & 2 & 2 \\
\hline Total & 86 & 42 & 128 & 100 \\
\hline
\end{tabular}

A hypopyon was present in 69 eyes, two-thirds of these being central bacterial ulcers. More than $80 \%$ of the hypopyons were $2 \mathrm{~mm}$ or less at the time of presentation. A significant corneal isolate was obtained in 45 of the 69 eyes, 17 of which were pneumococci. Ten of the 30 ulcers in the marginal catarrhal group were associated with hypopyon.

All aerobic bacterial isolations were tested for antibiotic susceptibility with a modified Kirby-Bauer disc diffusion technique on blood agar plates. All isolates were sensitive to either cefazolin or gentamicin, which were the two antibiotics used in treating the bacterial infections.

\section{Discussion}

Patients with many different types of corneal ulcers present for treatment at St John's Eye Hospital every year. As a general rule, owing to a shortage of beds (110 beds), only fairly severe cases will receive inpatient treatment, and this group of patients included 69 with hypopyon and 34 with perforated corneal ulcer. Most of the patients were male Africans, half of whom were manual labourers. This group might be expected to be exposed to corneal trauma, and indeed corneal foreign bodies and other corneal injuries such as corneal abrasions were the commonest local predisposing factors, followed by nodular climatic droplet keratopathy. The differences in the numbers of patients from various ethnic groups probably reflect differences in population size. The marked male predominance has commonly been reported and was as high as $80 \%$ in a retrospective study of 677 cases. $^{2}$

The class system for the isolates is intended to assess relevance of isolates and exclude contaminant bacteria. From class 1 to class 5 presents a decreasing likelihood of significance. Florid growth of an organism in several media (class 1) would be highly significant, whereas recovery of a pathogen only from the conjunctiva would be of questionable significance. The latter isolate may be considered when pretreatment is suspected of having sterilised the cornea. Classes 4 and 5 are included in an attempt to use conjunctival isolates in a meaningful way rather than relying only on corneal specimens. A class 4 isolate may reflect a tear film contaminant such as Staph. epidermidis or a more fastidious organism that will grow only on a certain type of medium, such as Moraxella species in serum broth of cornea and conjunctiva. Conjunctival isolates obtained which did not occur as class 4 or 5 isolates are not reported in this paper.

Bacterial corneal ulcers constituted the largest group of ulcers seen, and pneumococci were prominently isolated within the group. Staph. aureus is usually the commonest Gram-positive bacterium reported as a cause of central bacterial keratitis,,$^{1-46}$ though an early series reported by Thygeson ${ }^{12}$ showed pneumococci to be causative in $70 \%$ of 50 central corneal ulcers. The difference in the range of organisms is at least partly due to a worldwide difference in the conjunctival sac carrier rates of various organisms.' In a large series LocatcherKhorazo and Seegal ${ }^{1}$ showed a high $(13 \%)$ carrier rate of pneumococci in the normal conjunctival sac in the children under 5 but only $2-3 \%$ thereafter. In the same series the carrier rate of Staph. aureus was $25 \%$ in the children under 5, but this remained constant in all age groups thereafter. In this study five children had pneumococcal ulcers, four of whom were under 5 years old (three were central bacterial ulcers). The other pneumococcal ulcers were evenly spread through the age groups over 20 years.

Pneumococcal typing is not particularly useful in that the organisms usually reflect upper respiratory tract pneumococci.' This was found to be true in this 
study, though the types of pneumococci predominantly found differed from those previously reported. As multiply resistant pneumococci have been reported from South Africa, ${ }^{1314}$ a careful watch was kept for these organisms, but none was found. Ps. aeruginosa and Moraxella species were the two commonest Gram-negative isolates in the population studied. Moraxella corneal ulcers have been described as occurring in derelict populations, who have a high carrier rate of these organisms in their noses and conjunctival sacs. ${ }^{15}$ The carrier rate in our area is not known.

Direct smears were found to be significantly more helpful in central as opposed to marginal ulcers $(\mathrm{p}<0.05$, normal deviate test). This difference was largely due to the fact that an organism could be identified from many of the central ulcers. The results confirm the fact that, if an organism is seen on the smear, it is very likely to be the causative organism, but if no organism is seen there is still a $50 \%$ chance that an organism will be cultured.

Only 24 cases of dendritic keratitis were seen during the year (two admitted and 22 treated at outpatients). This might represent a racial difference in susceptibility, and in support of this seven of the 24 were coloured and one Asian. This was the only group of ulcers with such a large proportion of race groups other than African. There are many clinics throughout Soweto and the surrounding areas, and certainly many corneal ulcers are prevented or treated at an early stage by these primary health care workers. To some extent, therefore, the patients presenting to St John's for treatment represented a 'screened' population, but many 'mild' cases were seen, as well as referral problem cases, and it is unlikely that the dendritic ulcer patients were being selectively screened out.

The 60 catarrhal corneal ulcers treated during the year (half at outpatients and half admitted) testify that chronic staphylococcal blepharitis/ meibomianitis and its sequelae were commonly seen, often with a secondary bacterial infection.

When dealing with large numbers of corneal ulcers the culture technique used must be accurate and yet reasonably quick to perform. The multiple scrape technique, described by Jones, " was largely successful in view of the fact that half the cases had been pretreated with antibiotics. The use of multiple media is essential if significance is to be determined and contaminants recognised. The serum broth was supplied in Bijou bottles and the brain-heart infusion and chopped meat in McCartney bottles, which made transport easier than with media in tubes.

Reliable isolation of anaerobic bacteria is more time-consuming than of aerobic bacteria, and indications are that these organisms should not be ignored.
Corneal ulceration caused by anaerobic bacteria was considered uncommon enough to warrant single case reporting from the 1950s into the 1970s. ${ }^{16-19}$ In 1977 Jones and Robinson reviewed the subject ${ }^{20}$ and included details of five cases of anaerobic keratitis. They also proposed guide lines for defining a significant isolate. Perry et al. ${ }^{21}$ reported 11 cases of anaerobic corneal ulcer, using very stringent criteria for case definition, from a series of 162 bacterial corneal ulcers. All these cases ${ }^{2121}$ had some predisposing factor(s). Anaerobic bacteria may be pathogenic alone or acting synergistically with aerobic bacteria as has been suggested..$^{22}{ }^{23}$ The practical implications of this group of organisms with respect to treatment is uncertain, as they are usually susceptible to the same antibiotics as have been used for aerobic bacterial keratitis. A change to chloramphenicol is recommended ${ }^{21}$ once an anaerobe is isolated, but this information may not be available in time to be useful.

If bacteriology is to play an active role in the management of acute keratitis, provisional results must be available within 24 hours, as these cases can deteriorate rapidly. It was pleasing to note during the study period that in nine cases of uncontrolled infection (six pneumonococcal and three pseudomonas) the organism was identified in eight cases on the day of admission on direct smear and provisionally confirmed on culture the following day. This places the clinician in the best possible position to make decisions on antibiotic choices in spite of having to wait a further day for antibiotic sensitivity results. It is usually sufficient to be able to make a distinction between Gram-positive cocci and Gramnegative bacilli for the purpose of choosing an antibiotic. Mixed infections are common enough to keep one humble, and a broad spectrum of antibiotic cover is used initially, with a change to more specific treatment made with positive confirmation of the causative organism.

Dr L'D Ormerod suggested the study and Dr E T Meyer's assistance is gratefully acknowledged. The laboratory personnel provided useful comments, and suggestions and the registrars and nursing staff at St John's Eye Hospital made the study possible.

\section{References}

1 Locatcher-Khorazo D, Seegal BC. Microbiology of the eye. St Louis: Mosby, 1972: 14, 16, 69, 71 .

2 Asbell P, Stenson S. Ulcerative keratitis-survey of 30 years' laboratory experience. Arch Ophthalmol 1982; 100: 77-80.

3 Licsegang TJ, Forster RK. Spectrum of microbial keratitis in South Florida. Am J Ophthalmol 1980; 90: 38-47.

4 Chaudhuri PR, Godfrey B. Treatment of bacterial corneal ulcers with concentrated antibiotic eye drops. Trans Ophthalmol Soc UK 1982; 102: 11-4.

5 Gugnani HC, Talwar RS, Njoku-Obi ANU, Kodilinye HC. Mycotic keratitis in Nigeria. Br J Ophthalmol 1976; 60: 607-13. 
6 Jones DB. Initial therapy of suspected microbial corneal ulcers. II. Specific antibiotic therapy based on corneal smears. Surv Ophthalmol 1979; 24: 97, 105-16.

7 Bron AJ. A simple scheme for documenting corneal disease. Br J Ophthalmol 1973; 57: 629-34.

8 Harrison SM. Grading corneal ulcers. Ann Ophthalmol 1975; 7: $537-42$.

9 Jones DB. Early diagnosis and therapy of bacterial corneal ulcers. Int Ophthalmol Clin 1973; 13: 1-29.

10 Buchanan RE, Gibbons NE, eds. Bergey's Manual of determinative bacteriology. 8th ed. Baltimore: Williams and Wilkins, 1974.

11 Kimura SJ. Corneal ulcers. In: Infectious diseases of the conjunctiva and cornea. Symposium of the New Orleans Academy of Ophthalmology. St Louis: Mosby, 1963: 88-102.

12 Thygeson P. Acute central (hypopyon) ulcers of the cornea. Californ Med 1948; 69: 18-21.

13 Appelbaum PC, Bhamjee A, Scragg JN, Hallett AF, Bowen AJ, Cooper RC. Streptococcus pneumoniae resistant to penicillin and chloramphenicol. Lancet 1977; ii: 995-7.

14 Jacobs MJ, Koornhof HJ, Robins-Browne RM, Emergence of multiply resistant pneumococci. N EnglJ Med 1978; 299: 735-40.

15 Baum J, Fedukowicz HB, Jordan A. A survey of moraxella corneal ulcers in a derelict population. Am J Ophthalmol 1980; 90: 476-80.

16 Tsutsui J. Tetanus infection of cornea-its treatment with achromycin. Am J Ophthalmol 1957; 43: 772-4.

17 Gingrich WD, Pinkerton ME. Anaerobic Actinomycosis bovis corneal ulcer. Arch Ophthalmol 1962; 67: 549-53.

18 Ostler HB, Okumoto M. Anaerobic streptococcal corneal ulcer. Am J Ophthalmol 1976; 81: 518-9.

19 Majekodunmi S, Odugbemi T. Clostridium welchii corneal ulcer-a case report. Can J Ophthalmol, 1975; 10: 290-1.

20 Jones, DB, Robinson NM. Anaerobic ocular infections. Ophthalmology (Rochester) 1977; 83: 309-31.

21 Perry LD, Brinser JH, Kolodner H. Anaerobic corneal ulcers. Ophthalmology (Rochester) 1982; 89: 636-42.

22 Editorial: Bacterial synergy in mixed aerobic/anaerobic infections. Lancet 1980; i: 405-6.

23 Dankert J, Holloway Y, Bouwma J. Bacterial synergy in mixed aerobic/anaerobic infections. Lancet 1980; i: 714. 